\title{
Pokrzywa zwyczajna (Urtica dioica L.) - charakterystyka botaniczna, biochemiczna i właściwości prozdrowotne
}

\section{Stinging nettle (Urtica dioica L.) - botanical characteristics, biochemical composition and health benefits}

\author{
Karolina Jakubczyk, Katarzyna Janda, Sylwia Szkyrpan, Izabela Gutowska, Jolanta Wolska \\ Zakład Biochemii i Żywienia Człowieka Pomorskiego Uniwersytetu Medycznego w Szczecinie \\ ul. Broniewskiego 24, 71-460 Szczecin \\ Kierownik: prof. dr hab. n. med. Ewa Stachowska \\ Studium Doktoranckie Wydziału Nauk o Zdrowiu Pomorskiego Uniwersytetu Medycznego w Szczecinie \\ ul. Żołnierska 54, 71-210 Szczecin \\ Kierownik: prof. dr hab. n. med. Maria Laszczyńska
}

\section{SUMMARY}

Stinging nettle (Urtica dioica L.) belongs to the family Urticaceae. It grows in the wild form in Asia, Europe, North America and North Africa. Stinging nettle is also a widespread ruderal plant found in Poland. Urtica dioica L., as a plant rich in biologically active compounds, is considered one of the most important plants

\section{STRESZCZENIE}

Pokrzywa zwyczajna (Urtica dioica L.) należy do rodziny pokrzywowatych (Urticaceae). Rośnie w formie dzikiej w Azji, Europie, Ameryce Północnej i Afryce Północnej. Jako roślina ruderalna powszechnie znajduje się również w Polsce. Pokrzywa zwyczajna dzięki składowi bogatemu w związki biologicznie czynne uważana jest za jedną z najcenniejszych roślin stosowanych $w$ fitoterapii. $W$ modelach in vitro $i$ in vivo wykazano used in phytotherapy. In vitro and in vivo studies have demonstrated its antioxidant, antiplatelet, hypoglycaemic and hypocholesterolemic properties. Research conducted in recent years indicates the possibility of using nettle in chemoprevention, diabetes, benign prostatic hyperplasia and urologic diseases. Key words: stinging nettle, health benefits, phytotherapy.

\section{WSTĘP}

Pokrzywa zwyczajna (Urtica dioica L.) należy do roślin synantropijnych, przystosowujących się do życia w środowisku silnie przekształconym przez człowieka. Jako roślina ruderalna cieszy się obecnie coraz większym zainteresowaniem, a jej ogromny potencjał leczniczy opisywany był już w czasach starożytnych, m.in. przez Hipokratesa [1]. Na podstawie wyników badań klinicznych potwierdzono pozytywne efekty stosowania tej rośliny w leczeniu alergii, artretyzmu, cukrzycy oraz łagodnego rozrostu gruczołu krokowego. Nadal jednak poszukuje się nowych zastosowań pokrzywy zwyczajnej w zakresie profilaktyki oraz leczenia wielu chorób i dolegliwości. W pracy opisano skład chemiczny oraz właściwości prozdrowotne pokrzywy zwyczajnej w świetle najnowszego piśmiennictwa.

\section{CHARAKTERYSTYKA BOTANICZNA ROŚLINY}

Urtica dioica L., czyli pokrzywa zwyczajna, należy do rodziny pokrzywowatych (Urticaceae). Jest to wieloletnia, rozłogowa, jej właściwości antyoksydacyjne, przeciwzapalne, antyagregacyjne, hipoglikemiczne oraz hipocholesterolemiczne. Badania prowadzone w ostatnich latach wskazują na możliwość wykorzystania pokrzywy zwyczajnej w chemoprewencji, leczeniu cukrzycy, łagodnego rozrostu gruczołu krokowego oraz schorzeń urologicznych.

Słowa kluczowe: pokrzywa zwyczajna, właściwości prozdrowotne, fitoterapia. dwupienna roślina znana także pod nazwami: pokrzywa dwupienna, pokrzywa parząca, pokrzywa wielka, żagajka [2, 3, 4]. Sporadycznie występuje jako chwast jednopienny [4]. W zależności od stanowiska osiąga wysokość od 30 do ponad $100 \mathrm{~cm}$ [3]. Jest okryta parzącymi szczecinowatymi włoskami [5]. Posiada unoszącą się prosto ku górze nieparzystą lub lekko rozłożystą łodygę [4], która w pobliżu czerwonopurpurowej podstawy osiąga 0,2-1,4 cm grubości [6]. Na czworokanciastej łodydze naprzeciwlegle osadzone są ogonkowe liście grubo piłkowane na krawędzi, przy których znajdują się wąskie przylistki. Blaszka liściowa u szczytu rośliny jest zaostrzona, o sercowatej nasadzie [3].

Czas kwitnienia i owocowania trwa od czerwca do października [7]. Kwiaty osadzone na długich szypułkach tworzą kwiatostany wyrastające z pachwin górnych liści. Kwiatostany o żółtozielonym zabarwieniu charakteryzują się wydłużonym kształtem. Kwiaty żeńskie od męskich różnią się wielkością listków okwiatu. W kwiatach męskich listki te są równe, natomiast w żeńskich niejednolitej wielkości. Kwiatostany znacznie różnią się u roślin żeńskich i męskich. U osobników męskich są ukierunkowane do góry, natomiast u roślin żeńskich opadają ku dołowi [3]. Owoc pokrzywy zwyczajnej jest 
owocem jednonasiennym, cienkościennym i gładkim. Nasiona o szerokości 0,7-0,9 mm, długości 1-1,5 mm i grubości 0,3 mm wypełniają cały owoc $[4,6]$.

\section{WYSTĘPOWANIE POKRZYWY ZWYCZAJNEJ}

Pokrzywa zwyczajna, podobnie jak typowy chwast, zasiedla gleby w okolicy domostw, ogrody, polany, pastwiska, zarośla, tereny w pobliżu jezior i rzek oraz lasy liściaste [5, 8]. Zazwyczaj występuje w dużych skupiskach na ziemiach obfitujących w azot, spotykana jest również na glebach o wysokim poziomie fosforanów [3, 7]. Zasięg występowania tej rośliny obejmuje całą półkulę północą [3]. Rośnie w formie dzikiej w Azji, Europie, Ameryce Północnej i Afryce Północnej, natomiast nie spotyka się jej na kole podbiegunowym północnym i w Afryce Południowej. Roślina ta jest chwastem ruderalnym, powszechnie rosnącym również w Polsce [5, 8].

\section{SKŁAD CHEMICZNY POKRZYWY ZWYCZAJNEJ}

Pokrzywa zwyczajna stanowi cenne źródło substancji biologicznie czynnych, dzięki czemu już od czasów starożytnych znajdowała zastosowanie jako lek. Cechuje się wysoką zawartością witamin, a także minerałów oraz innych organicznych związków, co szczegółowo przedstawiono w tabelach 1-7 [8, 9, 10, 11, 12, 13, 14, 15].

W podziale warzyw, owoców i ziela ze względu na zawartość witaminy $C$ na cztery grupy (A, B, C, D) pokrzywę zwyczajną zaliczono do grupy A. Znajdują się tu rośliny o najwyższej zawartości witaminy C, powyżej 500 mg\% (mg/100 g). Według Nowak [16] ziele pokrzywy zwyczajnej zawiera do $600 \mathrm{mg} \%$ witaminy C. Pokrzywa zawiera 9-21\% włókna surowego (86,5\% włókna uzyskanego z tej rośliny stanowi celuloza) i 21-23\% białka surowego (ogólnego). Nasiona pokrzywy zwyczajnej to bogate źródło oleju - jego ilość określono na poziomie 30,68\%. Olej z nasion pokrzywy to źródło wielonienasyconych, jednonienasyconych i nasyconych kwasów tłuszczowych, z przewagą kwasu linolowego i oleinowego [10]. Substancje obecne w pokrzywie zwyczajnej mogą stanowić źródło niedoborowych w organizmie ludzkim składników, niezbędnych w wielu szklakach metabolicznych [8].

\section{WŁAŚCIWOŚCI PROZDROWOTNE POKRZYWY ZWYCZAJNEJ}

Korzystanie z surowców roślinnych jako funkcjonalnych składników żywności, napojów i kosmetyków zyskuje coraz większe zainteresowanie zarówno wśród naukowców, jak i konsumentów oraz producentów. Do celów leczniczych wykorzystywane są liście zbierane przed kwitnieniem (Urticae folium), korzenie pozyskiwane jesienią lub wczesną wiosną (Urticae radix), a także całe ziele (Urticae herba). Istnieje jednak niewiele prac na temat zastosowania nasion (Urticae semen).
TABELA 1. Skład chemiczny liści pokrzywy zwyczajnej (Urtica dioica L.) [8, 9]

\begin{tabular}{|c|c|}
\hline $\begin{array}{l}\text { Grupy związków } \\
\text { biologicznie czynnych }\end{array}$ & $\begin{array}{l}\text { Zidentyfikowane związki w liściach } \\
\text { pokrzywy zwyczajnej (Urtica dioica L.) }\end{array}$ \\
\hline Witaminy & $\mathrm{B}_{2}, \mathrm{C}, \mathrm{K}, \mathrm{B}_{5}$ \\
\hline Kwasy organiczne & $\begin{array}{l}\text { protokatechowy, hydroksybenzoesowy, } \\
\text { gentyzynowy, chinowy, kumarowy, kawowy, } \\
\text { ferulowy, 5-O kawoilochinowy }\end{array}$ \\
\hline Karotenoidy & karoten, ksantofil, likopen, luteina \\
\hline Flawonoidy & $\begin{array}{l}\text { izoramnetyna, kwercetyna, kemferol, } \\
\text { rutyna, glikozydy, amentoflawon, glikozyd } \\
\text { kwercetyny }\end{array}$ \\
\hline Garbniki & taniny \\
\hline Związki organiczne & $\begin{array}{l}\text { chlorofil, 2-metyloheptan, skopoletyna, } \\
\text { eskuletyna, leukotrieny }\end{array}$ \\
\hline
\end{tabular}

TABELA 2. Skład chemiczny korzeni pokrzywy zwyczajnej (Urtica dioica L.) [8, 9]

\begin{tabular}{|c|c|}
\hline $\begin{array}{l}\text { Grupy związków } \\
\text { biologicznie czynnych }\end{array}$ & $\begin{array}{l}\text { Zidentyfikowane związki w korzeniach } \\
\text { pokrzywy zwyczajnej (Urtica dioica L.) }\end{array}$ \\
\hline Kwasy organiczne & $\begin{array}{l}\text { ursolowy, oleanolowy, } \\
\text { hydroksybenzoesowy, gentyzynowy, } \\
\text { chinowy, kumarowy, kawowy, ferulowy, } \\
\text { 5-0 kawoilochinowy }\end{array}$ \\
\hline Flawonoidy & rutyna, amentoflawon, glikozyd kwercetyny \\
\hline Garbniki & taniny \\
\hline Sacharydy & $\begin{array}{l}\text { glukan, glukogalakturoniany, } \\
\text { arabinogalaktany }\end{array}$ \\
\hline Kwasy tłuszczowe & linolowy, linolenowy \\
\hline Sterole & $\begin{array}{l}\text { sitosterole (7b-hydroxysitosterol, } \\
\text { stigmasterol, kampesterol) oraz } \\
\text { b-sitosterole (3-0-glukozyd) }\end{array}$ \\
\hline Fitoestrogeny & lignany \\
\hline Związki organiczne & $\begin{array}{l}\text { skopoletyna, eskuletyna, ceramidy, } \\
\text { sfingozyna, izolektyny, monoterpenoidole } \\
\text { oraz ich glikozydy, triterpeny, alkohol } \\
\text { homowanilinowy }\end{array}$ \\
\hline
\end{tabular}

TABELA 3. Skład chemiczny nasion pokrzywy zwyczajnej (Urtica dioica L.) $[9,10]$

\begin{tabular}{ll}
$\begin{array}{c}\text { Grupy związków } \\
\text { biologicznie czynnych }\end{array}$ & \multicolumn{1}{c}{$\begin{array}{c}\text { Zidentyfikowane związki w nasionach } \\
\text { pokrzywy zwyczajnej (Urtica dioica L.) }\end{array}$} \\
\hline Witaminy & $\begin{array}{l}\text { izomery tokoferolu: } \alpha, \gamma, \delta \text {-tokoferol } \\
\text { Krotokatechowy, hydroksybenzoesowy, } \\
\text { gentyzynowy, chinowy, kumarowy, kawowy, } \\
\text { ferulowy, 5-O kawoilochinowy }\end{array}$ \\
\hline Flawonoidy & rutyna, amentoflawon, glikozyd kwarcetyny \\
\hline Kwasy tłuszczowe & $\begin{array}{l}\text { palmitynowy, stearynowy, oleinowy, } \\
\text { linolowy, linolenowy, heneikozanowy }\end{array}$ \\
\hline Sterole & fitosterole \\
\hline Fitoestrogeny & lignany \\
\hline Związki organiczne & eskuletyna, skopoletyna \\
\hline
\end{tabular}

TABELA 4. Skład chemiczny włosków parzących pokrzywy zwyczajnej (Urtica dioica L.) $[8,9,11]$

\begin{tabular}{ll}
$\begin{array}{c}\text { Grupy związków } \\
\text { biologicznie czynnych }\end{array}$ & $\begin{array}{c}\text { Zidentyfikowane związki we włoskach } \\
\text { parzących pokrzywy zwyczajnej } \\
\text { (Urtica dioica L.) }\end{array}$ \\
\hline Kwasy organiczne & $\begin{array}{c}\text { mrówkowy, protokatechowy, } \\
\text { hydroksybenzoesowy, gentyzynowy, } \\
\text { chinowy, kumarowy, kawowy, ferulowy, } \\
\text { 5-O kawoilochinowy }\end{array}$ \\
\hline Flawonoidy & rutyna, amentoflawon, glikozyd kwarcetyny \\
\hline Związki organiczne & $\begin{array}{l}\text { histamina, aletylocholina, serotonina, } \\
\text { leukotrieny, eskuletyna, skopoletyna }\end{array}$ \\
\hline
\end{tabular}


TABELA 5. Skład chemiczny ziela pokrzywy zwyczajnej (Urtica dioica L.) $[9,12,13]$

\begin{tabular}{|c|c|}
\hline $\begin{array}{l}\text { Grupy związków } \\
\text { biologicznie czynnych }\end{array}$ & $\begin{array}{c}\text { Zidentyfikowane związki w zielu } \\
\text { pokrzywy zwyczajnej (Urtica dioica L.) }\end{array}$ \\
\hline Witaminy & $\mathrm{B}_{5}, \mathrm{C}$ \\
\hline Kwasy organiczne & $\begin{array}{l}\text { węglowy, mrówkowy, krzemowy, } \\
\text { cytrynowy, fumarowy, glicerynowy, } \\
\text { jabłkowy, szczawiowy, fosforowy, chinowy, } \\
\text { bursztynowy, masłowy, kawowy, kumarowy, } \\
\text { palmitynowy, neochlorogenowy, octowy, } \\
\text { kawoilo-jabłkowy, glikolowy, foliowy, } \\
\text { protokatechowy, hydroksybenzoesowy, } \\
\text { gentyzynowy, ferulowy, } \\
\text { 5-0 kawoilochinowy }\end{array}$ \\
\hline Karotenoidy & karoten, ksantofil \\
\hline Flawonoidy & $\begin{array}{l}\text { kwercetyna, rutyna, glikozydy, } \\
\text { izoramnetyna, kempferol, amentoflawon, } \\
\text { glikozyd kwercetyny }\end{array}$ \\
\hline Garbniki & taniny \\
\hline Sacharydy & $\begin{array}{l}\text { fruktoza, galaktoza, glukoza, maltoza, } \\
\text { rafinozy }\end{array}$ \\
\hline Kwasy tłuszczowe & linolowy, linolenowy \\
\hline Sterole & sitosterole, b-sitosterole (3-0-glukozyd) \\
\hline Związki organiczne & $\begin{array}{l}\text { skopoletyna (kumaryna), eskuletyna, } \\
\text { lecytyny, sekretyny, serotoniny, tryptaminy, } \\
\text { betainy }\end{array}$ \\
\hline
\end{tabular}

TABELA 6. Jakościowy skład pierwiastkowy części nadziemnych oraz podziemnych pokrzywy zwyczajnej (Urtica dioica L.) $[14,15]$

\begin{tabular}{lccc} 
Minerały & $\begin{array}{c}\text { Liść } \\
\text { (Urticae folium) }\end{array}$ & $\begin{array}{c}\text { Korzeń } \\
\text { (Urticae radix) }\end{array}$ & $\begin{array}{c}\text { Nasiona } \\
\text { (Urticae semen) }\end{array}$ \\
\hline $\mathrm{Mn}$ & + & + & - \\
\hline $\mathrm{Fe}$ & + & + & + \\
\hline $\mathrm{Cu}$ & + & + & - \\
\hline $\mathrm{Zn}$ & + & + & + \\
\hline $\mathrm{Mo}$ & + & + & - \\
\hline $\mathrm{Co}$ & + & + & - \\
\hline $\mathrm{Ni}$ & + & + & - \\
\hline $\mathrm{Se}$ & + & + & - \\
\hline $\mathrm{Al}$ & + & + & + \\
\hline $\mathrm{Sn}$ & + & + & + \\
\hline $\mathrm{Mg}$ & + & - & - \\
\hline $\mathrm{Ca}$ & + & - & - \\
\hline $\mathrm{Si}$ & + & + & - \\
\hline $\mathrm{As}$ & + & - & - \\
\hline $\mathrm{Cd}$ & + & - & - \\
\hline $\mathrm{Pb}$ & + & & - \\
\hline
\end{tabular}

Pokrzywa zwyczajna dzięki obecności dużej ilości substancji biologicznie czynnych wykazuje szerokie właściwości wykorzystywane przy leczeniu bądź wspomaganiu leczenia wielu chorób. Stosowanie ekstrakcji z zastosowaniem różnych rozpuszczalników pozwala na wyizolowanie z pokrzywy zwyczajnej związków biologicznie czynnych o charakterze hydrofilowym bądź hydrofobowym, o różnych właściwościach. W piśmiennictwie opisanych jest wiele badań przeprowadzonych in vitro i in vivo potwierdzających dobroczynne działanie Urtica dioica L. Należy jednak pamiętać, że istnieją też doniesienia opierające się jedynie na medycynie ludowej, niepotwierdzone szczegółowymi badaniami.
TABELA 7. Ilościowy skład pierwiastkowy części nadziemnych oraz podziemnych pokrzywy zwyczajnej (Urtica dioica L.) [15]

\begin{tabular}{lcc}
\multirow{2}{*}{ Minerały } & Liść (Urticae folium) & Korzeń (Urticae radix) \\
\cline { 2 - 3 } & \multicolumn{2}{c}{ mg/kg suchej masy } \\
\hline $\mathrm{Mn}$ & 57,84 & 28,18 \\
\hline $\mathrm{Fe}$ & 303 & 673 \\
\hline $\mathrm{Cu}$ & 13,23 & 12,71 \\
\hline $\mathrm{Zn}$ & 29,14 & 22,75 \\
\hline $\mathrm{Mo}$ & 4,265 & 0,733 \\
\hline $\mathrm{Co}$ & 0,084 & 0,485 \\
\hline $\mathrm{Ni}$ & 0,738 & 6,034 \\
\hline $\mathrm{Se}$ & 0,074 & 0,047 \\
\hline $\mathrm{Al}$ & 222 & 585 \\
\hline $\mathrm{Sn}$ & 10,22 & 2,77 \\
\hline
\end{tabular}

\section{WŁAŚCIWOŚCI ANTYALERGICZNE}

Pokrzywa zwyczajna stosowana jest w chorobach alergicznych ze względu na zawartość związków czynnych, m.in. pochodnych tyrozyny, wykazujących działanie przeciwhistaminowe. W badaniach in vitro stwierdzono, że ekstrakt z pokrzywy wykazuje działanie hamujące aktywność enzymów kilku kluczowych reakcji zapalnych powodujących objawy alergii sezonowej [17]. Związki o właściwościach przeciwzapalnych oraz antyalergicznych wykryto u zdrowych kobiet, które przyjmowały ekstrakt z pokrzywy zwyczajnej. Tak w moczu, jak i w surowicy wykryto nikotynamid, synefrynę, adeninę i oksykumarynę. Ponadto w moczu oznaczono dodatkowo witaminę B5, 4-shogaol i DL-metylo-m-tyrozyne, które nie występowały w surowicy, gdyż są szybko usuwane z krwi [18].

W innym badaniu z udziałem pacjentów sprawdzano wpływ liofilizowanego preparatu z pokrzywy zwyczajnej na zmniejszanie symptomów alergicznego nieżytu nosa. Po tygodniowym stosowaniu zaobserwowano u pacjentów istotną poprawę, jednak u kilku z nich zauważono reakcję alergiczną wywołaną spożywaniem zwiększonej ilości wyciągu z Urtica dioica L. [8, 19]. Eksperyment na linii komórkowej komórek tucznych (mastocytów) wykazał wpływ ekstraktu wodnego i wodno-alkoholowego z liści pokrzywy na tryptazę i receptory H1 powiązane $\mathrm{z}$ alergicznym zapaleniem błony śluzowej nosa (nieżyt nosa). Ekstrakt z pokrzywy hamuje tryptazę mastocytów oraz jest antagonistą wobec receptora histaminy $\mathrm{H} 1$ i powoduje ujemną aktywację agonisty tego receptora, chroniąc przed symptomami alergii sezonowych [17].

\section{WŁAŚCIWOŚCI PRZECIWZAPALNE I PRZECIWREUMATOIDALNE}

O przeciwbólowym działaniu pokrzywy zwyczajnej świadczą badania in vitro oraz in vivo. Uczestnicy eksperymentu cierpieli na bóle dysków i bóle spowodowane urazami mechanicznymi (zapalenie i naciągnięcie ścięgien, entezopatia nadkłykcia bocznego kości ramiennej - „łokieć tenisisty”, reakcje zapalne w kości i stawach). W grupie przyjmującej ekstrakt zauważono znaczną poprawę badanych czynników w stosunku do grupy kontrolnej [20]. Podobny eksperyment wykazał anaboliczny 
i przeciwzapalny wpływ ekstraktu z liści pokrzywy na komórki chrzęstne w testach in vitro [21]. Wyciąg z korzenia pokrzywy zwyczajnej zawiera inhibitory elastazy leukocytowej, cyklooksygenazy oraz 5-lipooksygenazy, dzięki czemu wykazuje działanie przeciwzapalne [12, 22]. Eksperyment przeprowadzony na hepatocytach dowiódł, że wyciągi alkoholowy oraz wodny z nasion pokrzywy zwyczajnej łagodzą stan zapalny poprzez zmniejszenie aktywności lipoksygenaz oraz ich produktów, które są mediatorami stanu zapalnego, oraz zmniejszają apoptozę i nekrozę w komórkach [23]. Ponadto, w badaniach in vitro wykazano, że polisacharydy wyizolowane z wodnych wyciągów z korzeni pobudzają limfocyty T oraz układ dopełniacza, dzięki czemu podnoszą odporność organizmu. Właściwości te znalazły zastosowanie przy leczeniu zapalenia stawów.

Stwierdzono, że ekstrakt może zapewnić także tymczasową ulgę w bólach reumatycznych [24, 25, 26, 27]. W systemie in vitro ekstrakt z liści pokrzywy w postaci leku Hoxalpha (stosowanego w leczeniu chorób reumatycznych) wpłynął hamująco na interleukinę 1 beta (IL-1ß), która ma zdolność stymulowania ekspresji metaloproteinazy macierzy 1, 3 i 9 w chondrocytach. Dzięki zdolności ekstraktu z liści pokrzywy do hamowania cytokiny (IL-1 $\beta$ ) udowodniono jego korzystne działanie w terapii przeciwreumatycznej oraz skuteczność dostępnego preparatu zawierającego pokrzywę [28]. Przeciwzapalne działanie pokrzywy zwyczajnej wykazali Genc i wsp. [29], udowodniając, że zmniejsza ona poziom cytokin zapalnych (TNF- $\alpha$, IL-1 $\beta$ ) oraz wpływa na poziom NF-кB.

\section{WŁAŚCIWOŚCI ANTYOKSYDACYJNE}

Potencjał antyoksydacyjny pokrzywy zwyczajnej potwierdziły liczne badania naukowe. Sprawdzono wpływ ekstraktu wodno-alkoholowego z Urtica dioica L. na stres oksydacyjny pacjentów przyjmujących 100 mg ekstraktu/kg masy ciała przez 8 tyg. W grupie badanej zaobserwowano, że ekstrakt powodował znaczący wzrost całkowitej zawartości przeciwutleniaczy i dysmutazy ponadtlenkowej, jednocześnie nie zmieniając peroksydazy glutationowej i dialdehydu malanowego [30]. Badanie przeprowadzone na hepatocytach intoksykowanych fluorkiem sodu wykazało, iż ekstrakt z nasion Urtica dioica L. posiada właściwości przeciwzapalne, antyapoptotyczne, a także zmniejsza ilość mitochondrialnych anionorodników ponadtlenkowych w tych komórkach [23]. Podobne wyniki uzyskali Toldy $i$ wsp. [31], których badania wykazały, że susz z liści pokrzywy (Urtica dioica L.) zmniejsza poziom reaktywnych form tlenu w mózgu szczura. Pokrzywa zwyczajna wykazała również efekt antyoksydacyjny w obecności aflatoksyny w erytrocytach, mózgu, wątrobie i nerkach szczurów [32]. Urtica dioica L. minimalizuje negatywne skutki wywołane u szczurów przyjmujących czterochlorek węgla $\left(\mathrm{CCL}_{4}\right)$, związek toksyczny zaburzający czynność wielu narządów, szlaków enzymatycznych i metabolicznych. Badania wykazały, że pokrzywa zmniejsza peroksydację lipidów, a jednocześnie zwiększa aktywność systemu obrony antyoksydacyjnej u szczurów leczonych $\mathrm{CCL}_{4}$ [33]. Antyoksydacyjne działanie pokrzywy zwyczajnej prawdopodobnie związane jest z wysoką zawartością związków biologicznie czynnych, przede wszystkim związków fenolowych. Do tej pory nie poznano molekularnego mechanizmu działania pokrzywy zwyczajnej odpowiedzialnego za zmianę równowagi pomiędzy procesami utleniania a systemem obronnym. Działanie ekstraktu z owocostanów Urtica dioica L. wydaje się zapobiegać powstawaniu reaktywnych form tlenu lub przyczyniać się do ich usuwania poprzez skuteczne działanie enzymów antyoksydacyjnych. Przypuszcza się, iż Urtica dioica L. zawiera znaczną ilość miedzi, cynku oraz selenu, będących niezbędnymi kofaktorami enzymów antyoksydacyjnych.

\section{WŁAŚCIWOŚCI ANTYAGREGACYJNE}

Badania na zdrowych osobach w wieku 20-35 lat wykazały, iż świeża i sproszkowana pokrzywa ma działanie antyagregacyjne. Eksperyment przeprowadzono na wyizolowanych trombocytach z krwi żylnej pacjentów. Potwierdzono, że pokrzywa nie hamuje agregacji płytek krwi indukowanej kolagenem, kwasem arachidonowym oraz trombiną, natomiast zatrzymuje agregację płytek krwi wywołaną przez difosforan adenozyny [34]. Przeprowadzono także eksperyment sprawdzający wpływ różnych ekstraktów z liści pokrzywy zwyczajnej na agregację płytek krwi u szczurów w systemie in vitro. Ekstrakcja z liści Urtica dioica L. w różnych rozpuszczalnikach (metanol, eter naftowy, octan etylu i woda) wykazała, że ekstrakt w octanie etylu wykazuje największe działanie, natomiast surowy ekstrakt wodny hamował, w sposób zależny od dawki, indukowaną trombiną agregację płytek krwi. Z liści pokrzywy wyizolowano flawonoidy - związki mające szczególne znaczenie w działaniu przeciwpłytkowym. Flawonoidy istotnie hamują agregację płytek krwi indukowaną nie tylko trombiną, ale również przez adrenalinę, kolagen i difosforan adenozyny. Badania te doprowadziły naukowców do wniosku, że Urtica dioica L. ma istotne znaczenie w profilaktyce i leczeniu chorób sercowo-naczyniowych [35]. Pokrzywa zwyczajna ma również właściwości ochronne przed wpływem $\mathrm{CCL}_{4}$. Zależność tę sprawdzono u szczurów, badając u nich niektóre wartości hematologiczne i poziom $\mathrm{Cl}, \mathrm{K}$, Na oraz Ca. Po przeprowadzeniu analizy biochemicznej próbek krwi szczurów stwierdzono, że stosowanie Urtica dioica L. może łagodzić anemię, zwiększać poziom niektórych minerałów oraz ulepszać mechanizm obronny organizmu [36].

\section{WŁAŚCIWOŚCI HIPOGLIKEMICZNE I HIPOCHOLESTEROLEMICZNE ORAZ LECZENIE CUKRZYCY}

W badaniach in vitro lub in vivo wykazano korzystny wpływ pokrzywy zwyczajnej na wybrane czynniki ryzyka sercowo-naczyniowego. Dowiedziono pozytywnego działania zarówno u osób chorujących na cukrzycę, jak i zdrowych. Preparaty z kłączy i korzeni pokrzywy obniżają poziom cholesterolu, lipidów i glukozy we krwi. Badania in vivo oraz in vitro dowodzą 
wpływu wyciągu z Urtica dioica L. na zwiększenie wydzielania insuliny. Właściwości te z powodzeniem znalazły zastosowanie przy leczeniu cukrzycy oraz hipercholesterolemii [37]. Potwierdzono, że ekstrakt alkoholowy powoduje wzrost zużycia glukozy przez komórki mięśni poprzez podwyższenie wrażliwości na insulinę w tych komórkach lub w sposób bezpośredni poprzez zużycie glukozy [38]. Urtica dioica L. działa również antagonistycznie na PPAR gamma oraz hamująco na alfa-glukozydazy, co również związane jest z jej właściwościami hipoglikemicznymi oraz hipocholesterolemicznymi [39].

Hipoglikemiczny wpływ pokrzywy zwyczajnej został udokumentowany dzięki badaniom na szczurach. U zwierząt tych sztucznie wywoływano hiperglikemię poprzez podanie streptozotocyny bądź alloksanu. Przeprowadzono długo- i krótkoterminowe badania oceniające liczbę astrocytów w zakręcie zębatym w prawej półkuli u szczurów chorujących na cukrzycę indukowaną przez streptozotocynę. Grupa badana otrzymywała dootrzewnowo $100 \mathrm{mg}$ ekstraktu wodno-alkoholowego z pokrzywy zwyczajnej/kg mc./dzień przez okres 4 tyg., a w badaniach krótkoterminowych przez 5 dni. Liczba astrocytów u szczurów w obu grupach leczonych ekstraktem z pokrzywy w porównaniu do grupy kontrolnej z cukrzycą była niższa [40, 41]. W kolejnym eksperymencie sprawdzono wpływ wyciągu wodnego i alkoholowego z liści Urtica dioica L. podawanego przez 8 tyg. na liczbę i średnicę wysepek trzustkowych oraz parametry histologiczne u szczurów z cukrzycą wywołaną streptozotocyną. Wnioskowano, iż pokrzywa zwyczajna może spowodować naprawę tkanki trzustkowej [42]. W modelu in vivo i in vitro określono również wpływ ekstraktu wodnego i alkoholowego z liści Urtica dioica L. na działanie karboksylazy acetylo-CoA, kinazy difosfonukleozydowej oraz stężenie glukozy i poziom insuliny u szczurów zdrowych i z hiperglikemią. W celu wywołania cukrzycy doświadczalnej zwierzętom podawano alloksan. Grupa badana otrzymywała ekstrakt z liści pokrzywy zwyczajnej przez okres 2 tyg. W badaniu wykazano, że etanolowy i wodny wyciąg z pokrzywy zwyczajnej zwiększa aktywność zarówno kinazy difosfonukleozydowej, jak i karboksylazy acetylo-CoA. Ponadto udowodniono hipoglikemiczne działanie podanej pozajelitowo $U$. dioica L. u szczurów z hiperglikemią wywołaną alloksanem [43]. Ochronny wpływ ekstraktu z pokrzywy przed chorobami układu krążenia chorych na cukrzycę typu 2 potwierdziły badania na pacjentach, którym podawano $100 \mathrm{mg}$ ekstraktu wodno-alkoholowego z pokrzywy zwyczajnej/kg mc./dzień. Zaobserwowano poprawę parametrów takich jak: poziom glukozy, poziom triacylogliceroli, skurczowe ciśnienie krwi oraz poziom hemoglobiny glikowanej [30]. Potwierdzono hipoglikemiczne działanie ekstraktów z tej rośliny, jak również mniejszą polydypsje, poprawę wagi ciała, poziomu insuliny, poprawę zdolności poznawczych i czucia oraz zmniejszenie neuropatii należących do zaburzeń czynności centralnego i obwodowego układu neuronów u szczurów, u których wywołano cukrzycę streptozotocyną [44].

Najnowsze badania wykazały, iż wodny ekstrakt Urtica dioica L. zmniejsza o 60\% aktywność alfa amylazy trzustkowej. Inhibicja tego enzymu wykorzystywana jest w farmakologicznym leczeniu cukrzycy. Z badań wynika, iż pokrzywa zwyczajna może być zatem stosowana u osób z cukrzycą jako naturalny i bezpieczny lek, zastępując dostępne środki farmakologiczne o licznych skutkach ubocznych [45]. Urtica dioica L. stosowana u zwierząt ma również właściwości hipocholesterolemicze. Ekstrakt z pokrzywy zwyczajnej podawany w ilości $100 \mathrm{mg}$ i $300 \mathrm{mg} / \mathrm{kg}$ m.c. przez 28 dni istotnie zmniejszał stężenie lipoproteiny o niskiej gęstości, cholesterolu całkowitego, zmniejszał wagę oraz obniżał działanie enzymów wątrobowych u zwierząt, u których wywołano hiperlipidemię za pomocą koktajlu z oleju arachidowego [46]. Pokrzywa zwyczajna poprzez silne działanie przeciwutleniające powoduje wzrost tolerancji izolowanych serc przed zniszczeniem niedokrwiennym; $200 \mathrm{mg} / \mathrm{mL}$ wyciągu wodnego z pokrzywy zwyczajnej podanego $10 \mathrm{~min}$ przed niedokrwieniem i 10 min od początku reperfuzji potwierdziło ochronne działanie pokrzywy w stosunku do grupy kontrolnej [47].

\section{WŁAŚCIWOŚCI DIURETYCZNE}

W licznych doniesieniach opisywane są właściwości diuretyczne pokrzywy zwyczajnej jako rośliny należącej do akwaretyków, czyli leków wzmagających diurezę wodną [8, 48, 49]. Właściwość ta znalazła zastosowanie głównie przy leczeniu zaburzeń oddawania moczu towarzyszących przerostowi gruczołu krokowego (BPH). W badaniach in vitro oraz in vivo wykazano, że związki obecne przede wszystkim w korzeniach i kłączach pokrzywy zwyczajnej poprawiają proces oddawania moczu u chorych na BPH oraz wpływają na opróżnianie pęcherza, zmniejszenie obrzęku i dolegliwości bólowych przy oddawaniu moczu [48]. Komisja Europejska oraz ESCOP zalecają stosowanie korzeni pokrzywy zwyczajnej w leczeniu pierwszego i drugiego stadium BPH $[50,51]$. W badaniach in vivo potwierdzono pozytywny wpływ pokrzywy zwyczajnej w monoterapii, a także terapii skojarzonej na objawy BPH oraz częste oddawanie moczu [8]. Wyciąg z korzenia Urtica dioica L. podawany w ilości 378-756 mg przyczynia się do zmniejszenia częstotliwości oddawania moczu zarówno w nocy, jak i w dzień, zmniejsza zaleganie moczu oraz istotnie poprawia strumień moczu u 79,9\% badanych osób [49]. U pacjentów z przerostem gruczołu krokowego w pierwszym i drugim stadium, którym podawano codziennie przez okres 9 tyg. po $600 \mathrm{mg}$ bądź przez 6 miesięcy po 1200 mg ekstraktu z korzenia pokrzywy, odnotowano spadek częstości oddawania moczu. Wzrost $5 \alpha$-DHT stwierdzono przy wyższej dawce i dłuższym czasie przyjmowania ekstraktu. Po przeanalizowaniu wyników przedstawiających poziom białka biorącego udział w transporcie testosteronu (SHGB) stwierdzono, że w obu badaniach nastąpił spadek jego poziomu [52,53]. Badania na zwierzętach także wskazują na skuteczność stosowania ekstraktu z korzeni pokrzywy zwyczajnej przy łagodzeniu objawów BPH. W celu wywołania objawów przerostu gruczołu krokowego u chomików przez 30 dni podawano testosteron oraz ekstrakt Urtica dioica L. Wykazano, że pokrzywa ma antyandrogenny efekt i antagonizuje działanie testosteronu, wpływając na polepszenie struktury jąder oraz zmniejszenie zmian histologicznych wywołanych przez testosteron [54]. Nikotyna stanowi istotny 
czynnik zwiększający ryzyko BPH. Wodno-alkoholowy ekstrakt podawany myszom przez 28 dni wykazał ochronne działanie na jakość spermy oraz zmniejszył negatywny efekt wywołany przez nikotynę [55]. W wynikach najnowszych badań wykazano również hamujące działanie pokrzywy zwyczajnej na powstawanie kamieni moczowych u szczurów, u których wywoływano to schorzenie. Metanolowy wyciąg z nadziemnych części rośliny obniżał w moczu podwyższone poziomy wapnia, szczawianu i kreatyniny, znacznie zmniejszając ich osadzanie w nerkach [56]. Wyniki badań sugerują, że Urtica dioica L. wykazuje potencjał jako naturalny środek terapeutyczny do leczenia różnych zaburzeń urologicznych.

\section{WŁAŚCIWOŚCI PROTEKCYJNE}

Wyciągi z pokrzywy są stosowane przeciwko niewydolności wątroby oraz w zapobieganiu uszkodzeniom struktury wątroby szczura [57, 58]. W hepatocytach inkubowanych z alkoholowym wyciągiem nasion pokrzywy odnotowano mniejszą aktywność mediatorów stanu zapalnego, a także zmniejszoną apoptozę oraz nekrozę w komórkach wątrobowych, co świadczy o hepatoprotekcyjnym działaniu wyciągu [23]. W badaniach na szczurach przyjmujących $\mathrm{CCL}_{4}$ oraz ekstrakt z pokrzywy odnotowano zmniejszoną aktywność enzymów wątrobowych oraz peroksydację lipidów [33]. U szczurów z uszkodzeniem wątroby wywołanym przez niedrożność dróg żółciowych wykazano, iż pokrzywa osłabia indukowane podwiązanie dróg żółciowych, uraz wątroby, zastój żółci, proliferację i zwłóknienie dróg żółciowych [59]. Badanie na szczurach z ostrym zapaleniem trzustki, którym podawano ekstrakt z pokrzywy zwyczajnej, wykazało mniejsze zmiany histopatologiczne oraz mniejszą apoptozę w grupie badanej, co wskazuje na ochronny efekt pokrzywy zwyczajnej [60].

\section{WŁAŚCIWOŚCI PRZECIWBAKTERYJNE}

W medycynie ludowej pokrzywa zwyczajna była stosowana do przyspieszania procesu gojenia się ran. Zastosowanie to znalazło potwierdzenie w badaniach naukowych wykazujących jej właściwości przeciwbakteryjne. Metanolowy ekstrakt z pokrzywy wykazał działanie przeciwbakteryjne wobec szczepów gronkowca złocistego opornego na metycylinę (methicillin-resistant Staphylococcus aureus) [61]. Udowodniono również aktywność przeciwbakteryjną wyciągów z pokrzyw przeciwko lekooporności szczepu Mycobacterium tuberculosis (multidrug resistant tuberculosis) [62]. Ekstrakt z pokrzywy zwyczajnej może być stosowany jako naturalny środek antyseptyczny i przeciwbakteryjny.

\section{WŁAŚCIWOŚCI PRZECIWNOWOTWOROWE}

W Turcji nasiona i wodny wyciąg z nadziemnych części rośliny używane są powszechnie jako ziołowy lek przez chorych na nowotwory [63], natomiast w Europie alkoholowy wyciąg z pokrzywy jest z powodzeniem stosowany przy leczeniu raka prostaty [48]. Prawdopodobnie działanie antynowotworowe wyciągu z pokrzywy wykorzystywane przy leczeniu raka prostaty wynika ze zdolności jej składników (fitoestrogenów) do obniżania stężenia SHGB, czyli globulin wiążących hormony płciowe: androgeny i estrogeny. W korzeniach pokrzywy stwierdzono wysoką zawartość takich fitoestrogenów jak lignany, które wchodzą w interakcje z SHGB. Dzięki obecności protein wiążących hormony płciowe dochodzi do wzrostu poziomu aktywnych (biodostępnych) hormonów, co wpływa na ograniczenie przerostu prostaty. Pokrzywa wykazuje także właściwości hamujące nadmierną aktywność aromatazy, enzymu transformującego testosteron do enzymów należących do grupy estrogenów (np. estronu i estradiolu), która związana jest z łagodnym rozrostem gruczołu krokowego. Prawdopodobnie za łagodzenie objawów BPH odpowiedzialne są substancje biologicznie czynne zawarte w korzeniu, a mianowicie lektyny i polisacharydy hamujące aktywność aromatazy [64]. W badaniach in vitro wykazano ponadto, że ekstrakt z Urtica dioica L. hamuje proliferację komórek nowotworowych, m.in. komórek nowotworowych raka piersi $[63,65]$. Najnowsze badania donoszą o antymutagennym wpływie nadziemnych części pokrzywy zwyczajnej w badaniach z mutagenem 2-aminoantracenem. Autorzy sugerują, iż działanie to może wynikać z hamowania CYP450, biorącego udział w aktywacji biologicznej mutagenów. Zdolność wymiatania wolnych rodników tlenowych prawdopodobnie przyczynia się do antymutagennego działania rośliny, co może być wykorzystane w przyszłości przy chemoprewencji [66].

\section{BEZPIECZEŃSTWO STOSOWANIA POKRZYWY ZWYCZAJNEJ}

Pokrzywa zwyczajna z powodzeniem może być stosowana jako naturalny i bezpieczny lek przy wielu schorzeniach. Roślina ta jest bezpieczna i nie wpływa toksycznie na komórki [67]. Brak poważnych skutków ubocznych potwierdzono także w licznych badaniach z udziałem pacjentów przyjmujących ekstrakt z pokrzywy zwyczajnej przez okres 3-24 miesięcy, co świadczy o jego bezpieczeństwie w terapii długoterminowej [22].

\section{PODSUMOWANIE}

W dzisiejszych czasach pozycja medycyny niekonwencjonalnej jest stabilna i rośnie w siłę. Rośliny wykorzystywane przy fitoterapii stanowią cenne źródło naturalnych składników o wielu właściwościach. Zaletą wielu ziół jest również ich powszechne występowanie, łatwa uprawa, a także stosowanie przy ich przerobie prostych zabiegów technologicznych. Pokrzywa zwyczajna wydaje się być obiecującą rośliną, mającą ogromny potencjał leczniczy. Bogaty skład czynników bioaktywnych zawartych w częściach nadziemnych oraz podziemnych tej 
rośliny wpływa m.in. na jej właściwości antyoksydacyjne, przeciwzapalne, antyagregacyjne, hipoglikemiczne oraz hipocholesterolemiczne. Cechy te umożliwiają stosowanie pokrzywy zwyczajnej jako rośliny leczniczej w wielu chorobach. W ostatnich latach badacze skupiali swoją uwagę przede wszystkim na korzystnym wpływie pokrzywy zwyczajnej na alergię, artretyzm, cukrzycę oraz łagodny rozrost gruczołu krokowego. Nadal jednak poszukuje się nowych zastosowań leczniczych rośliny, a najnowsze badania donoszą o skuteczności pokrzywy zwyczajnej przy leczeniu nowotworów czy schorzeń urologicznych. Wydaje się, iż pokrzywa zwyczajna jako lek naturalny i bezpieczny może być z powodzeniem stosowana przy wielu chorobach.

\section{PIŚMIENNICTWO}

1. Nowiński M.: Dzieje upraw i roślin leczniczych. PWRiL, Warszawa 1983, 59-60.

2. Leksykon roślin leczniczych. Ed.: A. Rumińska, A. Ożarowski. PWRiL, Warszawa 1990

3. Grau J., Jung R., Münker B.: Leksykon przyrodniczy. Zioła i owoce leśne. Świat Książki, Warszawa 1996, 70, 252.

4. Činčura F., Ferákowá V., Májovský J., Šomšák L., Záborský J.: Pospolite rośliny środkowej Europy. PWRiL, Warszawa 1990, 140.

5. Nartowska J.: Pokrzywa zwyczajna. Panacea. 2007, 3 (20), 6-9.

6. Reaume T.: Stinging Nettle Urtica dioica, Urticaceae Nettle family. Nature Monitoba Grant, 2010 http://www.naturemanitoba.ca/sites/default/ files/StingingNettle.pdf. (21.01.2015).

7. Bisht S., Bhandari S., Bisht N.S.: Urtica dioica (L): an undervalued, economically important plant. Agric Sci Res J. 2012, 2 (5), 250-252.

8. Pieszak M., Mikołajczak P.Ł.: Właściwości lecznicze pokrzywy zwyczajnej (Urtica dioica L.). Postępy Fitoterapii. 2010, 4, 199-204.

9. Orčić D., Francišković M., Bekvalac K., Svirčev E., Beara I., Lesjak M. et al.: Quantitative determination of plant phenolics in Urtica dioica extracts by high-performance liquid chromatography coupled with tandem mass spectrometric detection. Food Chem. 2014, 15 (143), 48-53.

10. Uluata S., Özdemir $N$.: Antioxidant activities and oxidative stabilities of some unconventional oilseeds. J Am Oil Chem Soc. 2012, 89 (4), 551-559.

11. Akbay P., Basaran A.A, Undeger U., Basaran N.: In vitro immunomodulatory activity of flavonoid glycosides from Urtica dioica L. Phytother Res. 2003, 17 (1), 34-37.

12. ChrubasikJ.E., Roufogalis B.D., Wagner H., Chrubasik S.A.: A comprehensive on nettle efect and efficacy profiles. Part I: herba urticae. Phytomedicine. 2007, 14 (6), 423-435.

13. Guil-Guerrero J.L., Rebolloso-Fuentesa M.M., TorijaIsasab M.E.: Fatty acids and carotenoids from Stinging Nettle (Urtica dioica L.). J Food Composition Anal. 2003, 16 (2), 111-119.

14. Committee on Herbal Medicinal Products (HMPC). Assessment report on Urtica dioica L., Urtica urens L., Urtica folium. Europen Medicines Agency. 2010 http://www.ema.europa.eu/docs/en_GB/document_library/Herbal_-_HMPC_assessment_report/2012/11/WC500134484. pdf. (21.01.2015).

15. Mihaljev Z., Zivkov-Balos M., Cupić Z., Jaksić S.: Levels of some microelements and essential heavy metals in herbal teas in Serbia. Acta Pol Pharm. 2014, 71 (3), 385-391.

16. Nowak R.: Natura - niedoceniane źródło kwasu askorbinowego. Postępy Fitoterapii. 2004, 1, 14-18.

17. Roschek Jr B., Fink R., McMichae M., Alberte R.: Nettle extract (Urtica dioica) affects key receptors and enzymes associated with allergic rhinitis. Phytother Res. 2009, 23 (7), 920-926.

18. Ayers S., Roschek B.Jr., Williams J.M., Alberte R.S.: Pharmacokinetic analysis of anti-allergy and anti-inflammation bioactives in a nettle (Urtica dioica) extract. J Pharmacol Pharmacokin. 2008, 5, 6-21.

19. Mittman P.: Randomized, double-blind study of freeze-dried Urtica dioica in the treatment of allergic rhinitis. Planta Medica. 1990, 56 (1), 44-47.
20. Randall C., Meethan K., Randall H., Dobbs F.: Nettle sting of Urtica dioica for joint pain - an exploratory study of this complementary therapy. Complement Ther Med. 1999, 7 (3), 126-131.

21. Shakibaei M., Allaway D., Nebrich S., Mobasheri A.: Botanical extracts from rosehip (Rosa canina), willow bark (Salix alba), and nettle leaf (Urtica dioica) suppress IL-1ß-induced NF- $\kappa$ B activation in canine articular chondrocytes. Evid Based Complement Alternat Med. 2012; 2012: 16 .

22. Committee on Herbal Medicinal Products (HMPC). Assessment report on Urtica dioica L., Urtica urens L., their hybrids or their mixtures, radix. Europen medicines agency. 2012.

23. Gutowska I., Jakubczyk K., Dec K., Baranowska-Bosiacka I., Drozd A., Janda K. et al.: Effect of the extract from nettle (Urtica dioica L.) fruit cluster on the synthesis of pro-inflammatory agents in hepatocytes treated with fluoride. Fluoride. 2014, 47 (1), 113-122.

24. Wagner $H$., Willer $F$., Kreher B.: Biologically active compounds from the aqueous extract of Urtica dioica. Planta Med. 1989, 55 (5), 452-454.

25. Chrubasik S., Enderlein W., Bauer R., Grabner W.: Evidence for antirheumatic effectiveness of HerbaUrticae dioica in acute arthritis: a pilot study. Phytomedicine. 1997, 4 (2), 105-108.

26. Riehemann K., Behnke B., Schulze-Osthoff K.: Plant extracts from stinging nettle (Urtica dioica), an antirheumatic remedy, inhibit the proinflamma-

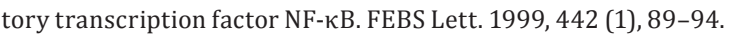

27. Hajhashemi $V$. ., Klooshani V.: Antinociceptive and anti-inflammatory effects of Urtica dioica leaf extract in animal models. Avicenna J Phytomed. 2013, 3 (2), 193-200.

28. Schulze-Tanzil G., de Souza P., Behnke B., Klingelhoefer S., Scheid A., Shakibaei $M$.: Effects of the antirheumatic remedy Hox alpha - a new stinging nettle leaf extract - on matrix metalloproteinases in human chondrocytes in vitro. Histol Histopathol. 2002, 17 (2), 477-485.

29. Genc Z., Yarat A., Tunali-Akbay T., Sener G., Cetinel S., Pisiriciler R. et al.: The effect of stinging nettle (Urtica dioica) seed oil on experimental colitis in rats. J Med Food. 2011, 14 (12), 1554-1561.

30. Namazi N., Esfanjani A.T., Heshmati J., Bahrami A., Nazemiyeh H.: A systematic review about effects of aerial portions of Urtica dioica (nettle) on some cardiovascular risk factors in diabetes mellitus. International Journal of Pharmacology. 2012, 8 (5), 306-313.

31. Toldy A., Stadler K., Sasvári M., Jakus J., Jung K.J., Chung H.Y. et al.: The effect of exercise and nettle supplementation on oxidative stress markers in the rat brain. Brain Res Bull. 2005, 65 (6), 487-493.

32. Yener Z., Celik I., Ilhan F., Bal R.: Effects of Urtica dioica L. seed on lipid peroxidation, antioxidants and liver pathology in aflatoxin-induced tissue injury in rats. Food Chem Toxicol. 2009, 47 (2), 418-424.

33. Kanter M., Coskun O., Budancamanak M.: Hepatoprotective effects of Nigella sativa $L$ and Urtica dioica $L$ on lipid peroxidation, antioxidant enzyme systems and liver enzymes in carbon tetrachloride-treated rats. World Journal of Gastroenterology. 2005. 11 (42), 6684-6688.

34. Pierre S., Crosbie L., Duttaroy A.K.: Inhibitory effect of aqueous extracts of some herbs on human platelet aggregation in vitro. Platelets. 2005, $16(8), 469-473$.

35. El Haouari M., Bnouham M., Bendahou M., Aziz M., Ziyyat A., Legssyer A. et al.: Inhibition of rat platelet aggregation by Urtica dioica leaves extracts. Phytother Res. 2006, 20, 568-572.

36. Meral I., Kanter M.: Effects of L. and L. on selected mineral status and hematological values in CCl4-treated rats. Biol Trace Elem Res. 2003, 96 (1-3), 263-270.

37. Testai L., Chericoni S., Calderone V., Nencioni G., Nieri P., Morelli I. et al.: Cardiovascular effects of Urtica dioica L. (Urticaceae) roots extracts: in vitro and in vivo pharmacological studies. J Ethnopharmacol. 2002, 81 (1), 105-109.

38. Mobaseri M., Aliasgarzadeh A., Bahrami A., Zargami N., Tabrizi A.: Efficacy of the total extract of Urtica dioica on the glucose utilization by the human muscle cells. J Clin Diagn Res. 2012, 6 (3), 437-440.

39. Kianbakht S., Khalighi-Sigaroodi F., Dabaghian F.H.: Improved glycemic control in patients with advanced type 2 diabetes mellitus taking Urtica dioica leaf extract: a randomized double-blind placebo-controlled clinical trial. Clin Lab. 2013, 59 (9-10), 1071-1076.

40. Jahanshahi M., Golalipour M.J., Afshar M.: The effect of Urtica dioica extract on the number of astrocytes in the dentate gyrus of diabetic rats. Folia Morphologica. 2009, 68 (2), 93-97. 
41. Golalipour M.J., Ghafari S., Latifimoghadam M.H., Kaboli S.: Alteration of dentate gyrus astrocy tes in diabetic rats: protective pole of Urtica dioica. Int J Morphol. 2011, 29 (4), 1307-1312.

42. Qujeq D., Tatar M., Feizi F., Parsian H., Faraji A.S., Halalkhor S.: Effect of Urtica dioica leaf alcoholic and aqueous extracts on the number and the diameter of the islets in diabetic rats. Int J Mol Cell Med. 2013, 2 (5), 21-26.

43. Qujeq D., Davary S., Moazzi Z., Mahjoub S.: Effect of Urtica dioica leaf extract on activities of nucleoside diphosphate kinase and acetyl coenzyme, a carboxylase, in normal and hyperglycemic rats. Afr J Pharm Pharmacol. 2011, 5 (6), 792-796.

44. Patel S.S., Udayabanu M.: Effect of Urtica dioica on memory dysfunction and hypoalgesia in an experimental model of diabetic neuropathy. Neurosci Lett. 2013, 552, 114-119.

45. Rahimzadeh M., Jahanshahi S., Moein S., Moein M.R.: Evaluation of alphaamylase inhibition by Urtica dioica and Juglans regia extracts. Iran J Basic Med Sci. 2014, 17, 465-469.

46. Nassiri-Asl M., Zamansoltani F., Abbasi E., Daneshi M.M., Zangivand A.A.: Effects of Urtica dioica extract on lipid profile in hypercholesterolemic rats. Zhong Xi Yi Jie He Xue Bao. 2009, 7 (5), 428-433.

47. Shackebaei D., Godini A.A., Abolghazi M., Majnouni M.B., Hesari M.: Protection of ischemic and reperfused rat heart by aqueous extract of Urtica dioica. Iran Cardiovasc Res J. 2010, 4 (3), 107-111.

48. Hirano T., Homma M., Oka K.: Effects of stinging nettle root extracts and their steroidal components on the $\mathrm{Na}+\mathrm{K}(+)$ - ATPase of the benign prostatic hyperplasia. Planta Med. 1994, 60, 30-33.

49. Nawrot J.: Herbal medicine in benign prostatic hyperplasia. HerbaPolonica. 2009, 55 (4), 214-223.

50. Blumenthal M., Busse W.R., Goldberg A.: The Complete German Commission E Monographs. Austin, TX: American Botanical Council. Integr Med Com, Boston 1998.

51. ESCOP Monographs, The Scientific Foundation for Herbal Medicinal Products. Thieme, Stuttgart-New York 2003.

52. Vontobel H., Herzog R., Rutishauser G., Kres H.: Results of a double-blind study on the effectiveness of ERU (extractum radicis Urticae) capsules in conservative treatment of benign prostatic hyperplasia. Urologe. 1985, 24 (1), 49-51.

53. Fischer M., Wilbert D.: Test of phytomedicine for treatment of benign prostatic hyperplasia (BPH). In: Benigne Prostahyperplasie III: Klinische und experimentelle Urologie. Vol 22. Ed. G. Rutishager. W. Zuckswerdt, New York 1992, 79-84.

54. Morovvati H., Najafzadehvarzi H., Rashidi K.: Effect of Urtica dioica extract on histological and histometrical changes of testis of hamster after testosteron administration. Zahedan J Res Med Sci. 2013, 15 (11), 4-8.
55. Jalili C., Salahshoor M.R., Naseri A.: Protective effect of Urtica dioica L against nicotine-induced damage on sperm parameters, testosterone and testis tissue in mice. Iran J Reprod Med. 2014, 12 (6), 401-408.

56. Zhang H., Li N., Li K., Li P.: Protective effect of Urtica dioica methanol extract against experimentally induced urinary calculi in rats. Mol Med Rep. 2014, 10 (6), 3157-3162.

57. Yesilada E., Honda G., Sezik E., Tabata M., Goto K., Ikeshiro Y.: Traditional medicine in Turkey. IV. Folk medicine in mediterranean Subdivision. J Ethnopharmacol. 1993, 39 (1), 31-38.

58. Lebedev A., Batakov E., Kurkin V.: The Antioxidative activity of a complex hepatoprotective preparation. silybokhol rastitel'nye resursy. 2001, 37 (2), 69-75.

59. Oguz S., Kanter M., Erboga M., Ibis C.: Protective effect of Urtica dioica on liver damage induced by biliary obstruction in rats. Toxicol Ind Health. 2013, 29 (9), 838-845.

60. Yilmaz B., Basar O., Aktas B., Altinbas A., Ekiz F., Büyükcam F. et al.: Effects of Urtica dioica extract on experimental acute pancreatitis model in rats. Int J ClinExp Med. 2014, 7 (5), 1313-1318.

61. Salehzadeh A., Asadpour L., Naeemi A.S., Houshmand E.: Antimicrobial activity of methanolic extracts of Sambucus ebulus and Urtica dioica against clinical isolates of methicillin resistant Staphylococcus aureus. Afr J Tradit Complement Altern Med. 2014, 11 (5), 38-40.

62. Singh R., Hussain S., Verma R., Sharma P.: Anti-mycobacterial screening of five Indian medicinal plants and partial purification of active extracts of Cassia sophera and Urtica dioica. Asian Pac J Trop Med. 2013, 6 (5), 366-371.

63. Konrad L., Muller H.H., Lenz C., Laubinger H., Aumaller G., Lichius J.J.: Antiproliferative effect on human prostate cancer cells by a stinging nettle root (Urtica dioica) extract. Planta Med. 2000, 66 (1), 441-447.

64. Dathe G., Schmid H.: Phytotherapy of benign prostate hyperplasia (BPH); double-blind study with stinging nettle root extract (Extractum Radicis Urticae - ERU). Urologe. 1987, 27, 223-226.

65. Fattahi S., Ardekani A.M., Zabihi E., Abedian Z., Mostafazadeh A., Pourbagher R. et al.: Antioxidant and apoptotic effects of an aqueous extract of Urtica dioica on the MCF-7 human breast cancer cell line. Asian Pac J Cancer Prev. 2013, 14 (9), 5317-5323.

66. Di Sotto A., Mazzanti G., Savickiene N., Staršelskytè R., Baksenskaite V., Di Giacomo $S$. et al: Antimutagenic and antioxidant activity of a protein fraction from aerial parts of Urtica dioica. Pharm Biol. 2015, 53 (6), 935-938.

67. Johnson T., Sohn J., Inman W.D., Bjeldanes L.F., Rayburn K.: Lipophilic stinging nettle extracts possess potent anti-inflammatory activity, are not cytotoxic and may be superior to traditional tinctures for treating inflammatory disorders. Phytomedicine. 2013, 20 (2), 143-147. 